\title{
Lumen
}

Selected Proceedings from the Canadian Society for Eighteenth-Century Studies

\section{'Too Much a Cento': Imitation as Invention in Pope's Mock-Heroic Poems}

\section{John Baird}

Volume 26, 2007

Imitation et invention au siècle des Lumières

Imitation and Invention in the Eighteenth Century

URI : https://id.erudit.org/iderudit/1012059ar

DOI : https://doi.org/10.7202/1012059ar

Aller au sommaire du numéro

Éditeur(s)

Canadian Society for Eighteenth-Century Studies / Société canadienne d'étude du dix-huitième siècle

ISSN

1209-3696 (imprimé)

1927-8284 (numérique)

Découvrir la revue

Citer cet article

Baird, J. (2007). 'Too Much a Cento': Imitation as Invention in Pope's

Mock-Heroic Poems. Lumen, 26, 35-48. https://doi.org/10.7202/1012059ar

Copyright (c) Canadian Society for Eighteenth-Century Studies / Sociéte canadienne d'étude du dix-huitième siècle, 2007
Ce document est protégé par la loi sur le droit d'auteur. L'utilisation des services d'Érudit (y compris la reproduction) est assujettie à sa politique d'utilisation que vous pouvez consulter en ligne.

https://apropos.erudit.org/fr/usagers/politique-dutilisation/ 


\section{3. 'Too Much a Cento': Imitation as Invention in Pope's Mock-Heroic Poems}

The Imitations of the Ancients are added, to gratify those who either never read, or may have forgotten them; together with some of the Parodies, and Allusions to the most excellent of the Moderns. If any man from the frequency of the former, may think the Poem too much a Cento; our Poet will but appear to have done the same thing in jest, which Boileau did in earnest; and upon which Vida, Fracastorius, and many of the most eminent Latin Poets professedly valued themselves.

Alexander Pope, 'Advertisement' to The Dunciad, Variorum, 17291

The Rape of the Lock is so firmly entrenched in our undergraduate survey courses as one of a handful of works deemed representative of the eighteenth century that we tend to forget just how exceptional generically it really is. As a device of style, the application of epic language to inappropriate subject matter, mock-heroic may indeed occur anywhere, from the Moretum ('Salad') of the Virgilian Appendix ${ }^{2}$ to James Joyce's Ulysses. As a genre, however, mock-heroic or mock-epic is a short-lived historical phenomenon, initiated in Italy by Alessandro Tassoni's La Secchia rapita (The Rape of the Bucket, 1622), naturalized in France by Nicholas Boileau Despréaux's Le Lutrin in 1674, brought to England by Samuel Garth in The Dispensary (1699), and exploited with equal brilliance in two different directions by Alexander Pope in The Rape of the Lock (1714) and in the various redactions of The Dunciad, first published in 1728 . After this poem, substantially augmented and retrofitted with a new protagonist, took its final form in 1743 , no new works of note

1 Alexander Pope, The Dunciad, Variorum 1729 (facsimile edition; Leeds: Scolar Press, 1966), 4. All references to the Variorum are to this facsimile, designated DV.

2 Translated, as 'Virgil's Salad,' by William Cowper, who had previously written a mock-heroic account of the cultivation of cucumbers, in The Task (1785), book 3. 
were produced in the genre. The long explanatory preface to Richard Owen Cambridge's eccentric Scribleriad (1752) merely underlines the degree to which mock-heroic, as genre, had lost its raison d'être. Only so long as literary standards were set by the classical models which formed the basis of genteel education could mock-heroic flourish, for beneath its surface clash of style and substance lies a deeper dichotomy between Ancient and Modern. ${ }^{3}$ Once the quarrel between Ancients and Moderns had begun to be resolved in favour of the Moderns, and of the vernacular rather than the classical tradition, the balanced tension between the two that makes a poem like The Rape of the Lock possible lost its equilibrium, and the genre died. ${ }^{4}$

Mock-epic or mock-heroic narrative is by its nature dependent on the prior existence of genuine epic narrative. It gains its typical effects by playing on its audience's awareness of its deliberate mismatch of style and substance, and the consequent disparity between its effects and the effects of true epic. Mock-epic invention is thus founded upon imitation; epic style must be imitated in order to be creatively misapplied to less than epic subject matter. Imitation is not limited, however, to this necessary generality of manner, but is frequently supplemented by specific imitations of particular passages in genuine epic. Such imitations intensify the deliberate incongruity of the genre, at the same time as they highlight the poet's skill in finding passages for witty imitation which are appropriate precisely because of their inappropriateness. This local intensification of the mock-heroic effect, however, brings with it some liabilities. First, it momentarily distracts attention from the narrative to the verbal texture in which that narrative is embodied, and beyond that to another text altogether. Second, if done too often, its distractive effect may reduce the mock-epic narrative to a mere patchwork of allusions and adaptations which lacks integrity. And, like all effects which depend upon recognition, it may not happen because the audience may, through ignorance or forgetfulness, miss it altogether. For successful deployment, specific imitations must be sufficiently numerous to establish them as an appreciable element in the overall effect, and care must be taken to alert the reader to their presence.

3 Hence the presence of irreconcilable conflicting codes that William Hutchings identifies as the defining oxymoronic feature of mock-heroic; see 'Boileau, Pope, and the mock-heroic,' Studies on Voltaire and the Eighteenth Century 292 (1991): 107-17.

4 See Howard Weinbrot, Britannia's Issue (Cambridge: Cambridge University Press, 1993), for the gradual displacement of classical standards by expectations based on native and vernacular (and thus Modern) models. 
The problems of distraction and non-recognition may be illustrated by a passage from a novel published in Pope's lifetime by another expert manipulator of the classical tradition, Henry Fielding. In book 3, chapter 9 of his 'comic epic poem in prose,' Joseph Andrews (1742) when the evil captain and his servants come to kidnap Fanny, they must first fight with Joseph and Parson Adams, and Joseph knocks the captain down:

Joseph . . lifted up a certain huge Stone Pot of the Chamber with one Hand ... and discharged it, together with the Contents, full in the Captain's Face. The uplifted Hanger dropped from his Hand, and he fell prostrate on the Floor with a lumpish Noise, and his Halfpence rattled in his Pocket; the red Liquor which his Veins contained, and the white Liquor which the Pot contained, ran in one Stream down his Face and his Clothes. ${ }^{5}$

Modern editors explain that this is an imitation of a recurrent line in the Iliad's battle scenes: 'He fell with a thud, and his armour clanged upon him. ${ }^{6}$ Those of Fielding's readers who remembered their Homer would enjoy this apt reduction of heroic immolation to fit the grubby violence of this episode, but even they are judged to need the nudge of italics to divert their attention from narrative to the different register of verbal felicity. And what of the 'mere English reader' of whose comfort Fielding is so solicitous in his 'Authors Preface'? He - or she - is left puzzled by what appears to be a typographical anomaly. Both types of reader are momentarily distracted from the narrative in hand. ${ }^{7}$

Distraction is ordinarily an unwelcome experience for readers, threatening to undermine their engagement with the text. Thus, for example, Johnson adjures the reader of Shakespeare to 'read on through brightness and obscurity, through integrity and corruption' in order to 'preserve his comprehension of the dialogue and his interest in the

5 Henry Fielding, Joseph Andrews, ed. Martin C. Battestin (Middletown, CT: Wesleyan University Press, 1967), 258.

6 Battestin's footnote to the passage quoted calls it 'Fielding's mock-heroic adaptation of a line that recurs in the Iliad,' and quotes the Greek. Current paperback editions give similar explanations.

7 This distraction, of course, plays into the general effect of the narrative by hinting to the reader not to take the fight and its consequences too seriously, disastrous though these at first appear. The italicization is preserved in all the editions of Fielding's lifetime, but many later eighteenth-century reprints drop it. 
fable.' Only when he is thoroughly familiar with the text should he read the commentators:

Particular passages are cleared by notes, but the general effect of the work is weakened. The mind is refrigerated by interruption; the thoughts are diverted from the principal subject; the reader is weary, he suspects not why; and at last he throws away the book, which he has too diligently studied. ${ }^{8}$

Interruptions and diversions may be the bane of ordinary reading, but The Dunciad is no ordinary work of literature. Its principal subject is literary failure; its dramatis personae are writers whose works are unreadable in every sense, a state of affairs summed up in the crushing reference to the Poet Laureate at the time of its publication: 'See also Eusden's whole Works (if to be found.)' (DV 7 [third pagination]; note to 1.71). Interruption in the contemplation of such literary non-being can hardly cause additional refrigeration of the mind; it may indeed be welcomed. The reading experience of The Dunciad aptly reverses the ordinary rules of literary engagement. The blanks and asterisks and bare initials of the 1728 edition left the reader constantly baffled, unable to comprehend who or what the poem was about; in The Dunciad, Variorum the blanks are filled with a vengeance, as the reader is swamped with information by a commentary that demands more sustained attention - and may be found more interesting - than the poem it ostensibly exists to support. ${ }^{9}$

For about a century, shared assumptions about literary culture disseminated through education created an audience that was capable of appreciating the special allusive effects of the mock-heroic genre. By 1729 , Pope hints, that audience was already losing its cultural competence; some of its constituents 'either never read, or may have forgotten' the masterpieces of the classical tradition. Such readers would simply miss the imitative dimension of the narrative, and thus fail to understand the poem. Bad enough if the poem were the story of a contention, as its

8 Samuel Johnson, 'Preface to Shakespeare, 1765,' in Arthur Sherbo, ed., Johnson on Shakespeare (The Yale Edition of the Works of Samuel Johnson, vol. 7; New Haven and London: Yale University Press, 1968), 111.

9 In his edition of The Dunciad (J. Butt, gen. ed., Twickenham Edition of the Poems of Alexander Pope [11 vols., London: Methuen, 1938-69], vol. 5 [3rd. ed., 1963], xx-xxi), James Sutherland mentions the possibility that Pope had originally intended to publish the poem with notes, but decided to issue it first without, and with hints that it was not the work of Pope, as a way of deflecting the hostility which would surely ensue. 
predecessors in the genre had been, but at least culturally incompetent readers of those poems could follow the storylines and get part of the effect. In the case of The Dunciad, however, the storyline lacks the focus of a quarrel, but instead supplies the slenderest narrative framework to articulate an indictment of Modern culture. Pope's epic, albeit a 'black' one, 'made out of the very impotence of poetry, ${ }^{10}$ requires special assistance for readers who cannot be relied upon to appreciate its quality. The massive apparatus added in The Dunciad, Variorum is designed not only to identify obscure writers and provide selectively damning information about their careers, but also to enlist the reader on Pope's side, as an adherent of classical standards and supporter of enduring Ancient values against the ephemeral productions of wretched Modernity.

This dual aim is reflected in the dual nature of the commentary, which is divided into two categories, 'Remarks' (discursive and informative) and 'Imitations' (citations of passages imitated in the text). ${ }^{11}$ In a well-known article, James McLaverty demonstrates that Pope drew this distinction from the 1716 Geneva edition of the works of Boileau, edited by the poet's admirer and disciple, Claude Brossette. ${ }^{12}$ As his title indicates, McLaverty's purpose in the article was theoretical; The Dunciad, Variorum provided an apposite example with which to clinch his argument. His discovery does, however, make possible a clearer view of Pope's polemical technique in the Variorum, to which the 'Imitations' make a significant contribution.

In the first place, Pope's mention of Boileau in the 'Advertisement' takes on fresh significance. He is drawing attention to an important similarity of presentation which reveals a contrast in practice, between Boileau's earnest and Pope's jest. English readers might be expected to be familiar with Boileau's poetry, if not with Brossette's edition. Boileau's general prestige, and familiarity to English readers, may be

10 Anthony David Nuttall, Pope's 'Essay on Man' (London: Unwin, 1984), 37.

11 The distinction is most unfortunately ignored in the apparatus of James Sutherland's edition of The Dunciad in the Twickenham Pope as a space-saving measure ('Note on the Text,' 5). The result of this decision has been that most readers of the poem in the last half-century have been unaware of a vital element in Pope's presentation of his poem.

12 'The Mode of Existence of Literary Works of Art: The Case of The Dunciad Variorum,' Studies in Bibliography 37 (1984): 83-106, esp. 100-4. McLaverty omits the comma in the book's title; I believe it is no mistake, but a device to emphasize the omission of the usual words 'cum notis.' This is not 'the Dunciad with the notes of various [writers],' but 'the Dunciad, of various [writers];' that is, the dunces have written themselves into the poem. 
gauged from the fact that as late as 1782 Vicesimus Knox lists him with Dryden and Pope, in contrast to Spenser and Milton, in a discussion of opposing tastes in English poetry. ${ }^{13}$

As Pope would have been very well aware, Brossette's edition itself has a polemical purpose. Boileau had begun his poetical career with a series of satires in which a number of his contemporaries were sharply criticized. Not surprisingly, he subsequently never lacked for detractors. In drawing on twelve years of correspondence with the master to furnish the reader with the 'Histoire secrete' of his works, ${ }^{14}$ Brossette sought not only to provide a commentary more extensive and more reliable than any editor lacking his access could provide, but also to enhance Boileau's reputation by emphasizing his artistic powers and integrity. This objective emerges clearly in his discussion of the third category of his notes, the 'Imitations.' Brossette's annotations, like Caesar's Gaul, are divided into three parts: first, in single column and slightly larger type, 'Changemens,' a record of variant readings; second, in double column and smaller type, 'Remarques,' or explanatory notes; finally, 'Imitations,' in single column, small type. The three elements do not occur on every page, but it is clear from variations in spacing and occasionally in font size, and notes running on to the subsequent page that the printer had some trouble accommodating this tripartite system of annotation.

In his 'Avertissement de l'Editeur,' Brossette defines 'imitations' simply as passages imitated from the Ancients, and continues: 'Bien loin qu'il eût honte d'avouer ces ingénieux larcins, il les proposoit, par forme de défi, à ses Adversaires qui s'avisoient de les lui reprocher: \& c'est lui qui m'a indiqué, dans la lecture suivie de tous les Ouvrages, les sources les plus détournées où il avoit puisé' (1:xi). For Brossette, Boileau's imitations of the Ancients raise him to rank with them; he took the thoughts of great authors and 'il s'en rendoit, pour ainsi dire,

13 Essays Moral and Literary, 2: 186; quoted (in another connection) by Linda Zionkowski in Catherine Ingrassia and Claudia N. Thomas, eds., 'More Solid Learning': New Perspectives on Alexander Pope's Dunciad (Lewisburg: Bucknell University Press, 2000), 129. Vida and Fracastorius, as neo-Latin writers, stand for modern exemplars of classical standards. Both were somewhat current in England at the time. Pope's admirer Christopher Pitt had published a translation of Vida's influential Art of Poetry in 1725, and in 1732 Richard Russel dedicated a new edition of his poetry to Pope in 1732. An edition of Fracastorius's best-known work, Syphilis. Sive Morbus Gallicus, appeared in London in 1720.

14 CEuvres de Mr. Boileau Despréaux. Avec des éclaircissemens historiques, donnez par luimême (2 vols.; Geneva: Fabri and Barillot, 1716), 1:vi. 
le maître, \& ne manquoit jamais de les embellir en les emploiant' (xi). Brossette cites many passages from the Ancients and from the Moderns in his explanatory notes under the heading 'Remarques,' but these are always cited in the course of some discussion of Boileau's text. 'Imitations' are noted without comment. The standard citation gives the line in Boileau's text (e.g., 'Vers 14.') an italicized quotation of all or part of the line and identification of the passage imitated (e.g., 'Horace, Art poëtique v.190') without any comment (315). There are a few exceptions ${ }^{15}$ but the general principle seems to be that identified imitations speak for themselves as testimony to Boileau's right to be ranked with the ancients.

By following Brossette's system of annotation, distinguishing 'Remarks' (explanatory notes) from 'Imitations,' Pope not only reproduces the appearance of his edition of Boileau but also gives himself an opportunity to highlight his artistry. ${ }^{16}$ For Pope, as for Boileau, skill in imitation of the Ancients is a means of defying his critics. It should not be surprising that Pope identifies more such imitations than Boileau (or Brossette) does. Each one serves as further proof of Pope's superiority over the authors whose inadequacies are unsparingly exposed in text and notes. ${ }^{17}$ If each serves also to make a satirical target ridiculous (Pope's 'in jest'), so much the better.

Comparison will demonstrate the extent to which Pope developed for his own purposes the methodology established by Brossette. Three samples, roughly comparable in size to The Dunciad, Variorum, will serve to demonstrate the role of imitation in Boileau as set out in Brossette's edition, and will show how Pope departed from his model to suit his own needs. Boileau's first major publication, his 'Discours au Roi' and seven satires, represents him as verse satirist, often critiquing bad writ-

15 For example, in L'Art Poétique, 3:71, where Brossette recalls Boileau's mockery of a rival's mistranslation (318), and 4:50, where he presents different versions of an ancient proverb (342). In both cases, the comments concern the passage imitated, not Boileau's text.

16 As McLaverty explains (102), Pope dropped 'Changemens' because Jonathan Richardson was keeping a comprehensive record of alterations to his poems. It seems likely that in 1729 Pope saw Richardson as his prospective Brossette; his acquaintance with William Warburton lay in the future.

17 The comments on the obscurity of the persons of The Dunciad in the 'Advertisement' ('it is only in this monument that they must expect to survive' [3; italics reversed]) seem to owe something to Brossette's words about the most obscure persons mentioned by Boileau, 'dont les noms seroient peut-être ignorés sans les Satires de nôtre Auteur' (1:vii). 
ers and bad writing. L'Art Poétique is his longest single work in verse, and its subject obviously invites literary allusions. Le Lutrin effectively initiated the English mock-heroic tradition in which Dryden, Garth, and Pope wrote. Table 1 indicates the number of lines identified as imitations in these selected works of Boileau and in The Dunciad, Variorum. It is apparent that Pope makes much more intensive use of imitations than Boileau, as reported by Brossette. The disparity between The Dunciad, Variorum and Le Lutrin is particularly notable. Brossette actually notes fewer imitations in the mock-heroic than in Boileau's other poems, whereas Pope makes mock-heroic the occasion of extensive citations of particular passages.

Table 1. Lines identified as imitations in selected works by Boileau and Pope's Dunciad, Variorum

\begin{tabular}{|l|l|l|l|l|}
\hline \multicolumn{2}{|l|}{ Disc. au Roi, Satires 1-7 } & $\begin{array}{l}\text { L'Art } \\
\text { Poétique }\end{array}$ & Le Lutrin & $\begin{array}{l}\text { Dunciad, } \\
\text { Variorum }\end{array}$ \\
\hline Lines & 1138 & 1100 & 1228 & 1015 \\
\hline Imitations & 58 & 58 & 27 & 86 \\
\hline Frequency & $1: 20$ & $1: 19$ & $1: 46$ & $1: 12$ \\
\hline
\end{tabular}

Differences in the authors cited are similarly striking, as shown in table 2 on page 43 .

In Brossette's presentation, Boileau's satires draw heavily on Horace's satires and epistles, and Juvenal's satires; his Art Poétique naturally looks to Horace's Ars Poetica. Horace and Juvenal are not cited in Le Lutrin, where Virgil's Aeneid is cited nine times to six for Homer's Iliad (there are four references to Virgil's Eclogues). Other classical authors appear much less frequently: in all three samples from Boileau's works, Martial and Persius are cited five times each, Cicero four times, Seneca three times, Ovid and Terence twice, and ten other Greek and Latin authors once each. Modern authors appear infrequently; in the satires, Regnier's satires are cited twice, and a poem by Malherbe and a letter in Latin by Cardinal Bembo once each. In Le Lutrin, there are four citations of Tassoni's La Secchia rapita, one of a compliment to Tassoni by his contemporary Le Querengo, and one of Corneille's comedy Le Menteur. 
Table 2. Citations of selected authors under 'Imitations'

\begin{tabular}{|l|l|l|l|l|}
\hline \multicolumn{2}{|l|}{ Disc. au Roi, Satires 1-7 } & $\begin{array}{l}\text { L'Art } \\
\text { Poétique }\end{array}$ & Le Lutrin & $\begin{array}{l}\text { Dunciad, } \\
\text { Variorum }\end{array}$ \\
\hline Horace & 18 & 49 & 0 & 3 \\
\hline Juvenal & 21 & 2 & 0 & 0 \\
\hline Virgil & 0 & 2 & 13 & 65 \\
\hline Other Latin & 11 & 14 & 3 & 8 \\
\hline Homer & 0 & 1 & 6 & 8 \\
\hline Other Greek & 3 & 0 & 0 & 1 \\
\hline The Bible & 0 & 0 & 1 & 0 \\
\hline Modern Authors & 4 & 0 & 6 & 22 \\
\hline
\end{tabular}

Note: Totals do not match figures in table 1 because some lines of Boileau and Pope are associated with more than one source under 'Imitations.'

In modifying Brossette's annotation of Boileau for his own purposes, Pope increased the proportion of identified imitations overall and the number of imitations of modern authors, as table 3 shows.

Table 3. Imitations in The Dunciad, Variorum

\begin{tabular}{|l|l|l|l|l|l|}
\hline Book & Lines & Imitations & Frequency & of ancients & of moderns \\
\hline 1 & 260 & 15 & $1: 17.3$ & 10 & 5 \\
\hline 2 & 397 & 38 & $1: 10.4$ & 27 & 11 \\
\hline 3 & 358 & 33 & $1: 10.8$ & 27 & 6 \\
\hline Total & 1015 & 86 & $1: 11.8$ & 64 & 22 \\
\hline
\end{tabular}

Notes: 1) Some lines identified as imitations are associated with more than one source.

2) There is one place in book 1 (line 146) where a reference to an earlier text that might have appeared under 'Imitations' appears in 'Remarks;' it is not clear whether this is deliberate on Pope's part. There also are places where notes of an explanatory kind appear under 'Imitations,' apparently because of typographical constraint $(1.6,79,89,93$, 96; $D V$ [second pagination] 2, 30); there also are places where explanatory material that would normally have appeared in 'Remarks' is placed under 'Imitations' where there is ample space for the other arrangement (1.106; $D \mathrm{~V}$ [second pagination] 31). Evidently these are matters in which consistency was difficult to maintain for Pope and his printers, and critical judgments based on the distinction between the two categories of annotation must always be liable to qualification. 
One might expect that Homer, as the originator of epic poetry as well as the object of Pope's efforts as translator for more than a decade, would figure prominently in the 'Imitations.' There are, however, only eight references to Homer, of which one is to an unidentified verse and three are general references to Homeric style. The only other Greek author mentioned is Lucian, but the lone citation of his Icaro-Menippus is significant because it draws attention to The Dunciad's relationship to the Menippean tradition..$^{18}$ Among the Latin writers cited, Boileau's favourite, Juvenal, does not appear at all, and Horace only three times. It is Virgil who dominates with a total of sixty-five citations, twelve to the Eclogues, four to the Georgics, and forty-nine to the Aeneid. The count here is equally lopsided; there are no references to books $3,4,8,9$, and 11 ; one to book 12 , three to book 10 , three to book 7 , four to book 2 , six to book 1 , ten to book 5 (mostly in the games of book 2), and twenty-two to book 6, the book that tells of Aeneas's visit to Hades under the guidance of the Sibyl. Of these twenty-two, all but three come from the last 220 lines of the book, that is, from Aeneas's culminating and prophetic encounter with his father Anchises, and his subsequent return from the underworld. Not surprisingly, references to Aeneid 6 dominate in the third book of The Dunciad (sixteen), but they are numerous in book 2 as well (seven).

These statistics, rudimentary as they are, confirm the comment made in the preface to the 1728 editions of The Dunciad, in which Pope, writing as 'the Publisher to the Reader,' remarks of the anonymous author of the poem: 'by the frequency of his allusions to Virgil, and a labor'd (not to say affected) shortness in imitation of him, I should think him more an admirer of the Roman Poet than of the Grecian, and in that not of the same taste with his Friend [i.e., Pope]' (DV [third pagination] 89). As Aubrey Williams has shown, this reference to Virgil is not merely a rather transparent mystification of the authorship of the poem but an important pointer to the way in which The Dunciad should be read. ${ }^{19}$ The preponderance of imitations of Virgil's Aeneid, book 6 throws light both on Pope's imaginative vision and on his rhetoric of classicism. His heavy emphasis on the epic of inheritance, refoundation, and the preservation of culture highlights and deepens by contrast the central

18 Christopher Fanning draws attention to Menippean elements in The Dunciad in 'Small Particles of Eloquence: Sterne and the Scriblerian Text,' Modern Philology 100 , no. 3 (2003): 360-92.

19 Aubrey L. Williams, Pope's Dunciad: A Study of Its Meaning (Baton Rouge: Louisiana State University Press, 1955), especially 16-29. 
themes of The Dunciad: willful rejection of the inherited wisdom of the past, disfoundation, and the destruction of culture. The concentration on book 6, and especially on the final episode, highlights the prophetic urgency of Pope's poem.

Referring to Latin epic rather than to Greek likewise has implications for the responses of readers. While certainly many classically educated men retained some knowledge of Greek, many more who had forgotten their Greek could still remember their Latin and their Virgil. Extensive 'imitation' of the Aeneid not only reinforced by contrast the themes of The Dunciad but also increased the likelihood that these 'imitations' would be recognized and appreciated.

A few examples will illustrate the ways in which 'Imitations' both confirm Pope's skill and invite the classically alert reader to join in mockery of Pope's targets. Early in book 1, the opening of the Aeneid is laid under contribution. The opening phrase, 'Books and the Man I sing,' provokes Scriblerus, in his opening 'Remark,' to conjecturally emend the beginning of Virgil's epic in a parody of Richard Bentley's scholarship. The first citation of the Aeneid in 'Imitations' comes at 1.33, where the 'Great Mother' (Dullness) and her love of the cave of Poverty and Poetry are celebrated. An unusually long quotation of four-and-ahalf lines (Aeneid 1.12, 15-18) reminds the reader of Juno's high regard for Carthage, a city, as the reader knows, destined for ruin. From the conjunction of Poverty and Poetry arise the various false works of literary art: 'Hence springs each weekly Muse, the living boast / Of Curl's chaste press, and Lintot's rubric post, / Hence hymning Tyburn's elegiac lay' (37-39). Here, focusing on the word 'Hence,' 'Imitations' directs us to Aeneid 1.6-7 and Virgil's salute to Latium, 'From whence the Race of Alban Fathers come, / And the long Glories of Majestick Rome,' as Dryden has it (6.9-10). ${ }^{20}$ The course of Roman history is thus ironically contrasted with ballads lamenting condemned felons sold at the place of execution.

In book 2, when Edmund Curll wins the booksellers' race for a plagiarist author after slipping in excrement, he 'vindicates the race, / Nor heeds the brown dishonours of his face' (99-100). 'Imitations' refers us to Aeneid 5.357-8, where Nisus shows his muddy person to support his claim for a prize in a race in which he slipped and fell. The incongruity between the young warrior, who, having fallen, tripped another runner

20 Quotations from Dryden's translation of the Aeneid follow the text of the edition by William Frost and Vinton A. Dearing in the California Edition, vol. 5 (1987), and are cited by book and line number. 
to ensure victory for his friend Euryalus and the untrustworthy Curll is emphatic. Two lines later, when the prize melts away in Curll's grasp, we are referred to Aeneid 6.701-2, the moment when Aeneas, meeting Anchises in the underworld, attempts to embrace the shade of his father. Bereft of the plagiarist, Curll tries to grab his papers, but these are blown away by the wind (105-09); 'Imitations' sends us to Aeneid 6.7475, where Aeneas begs the Sibyl, in Dryden's translation:

\author{
But oh! commit not thy prophetick Mind \\ To flitting Leaves, the sport of ev'ry Wind, \\ Lest they disperse in Air our empty Fate; \\ Write not, but, what the Pow'rs ordain, relate. (6.116-19)
}

In book 3, as Settle prophesies the triumph of Dullness, parodying Anchises in Aeneid 6, he instances as the first example of a dunce Theophilus Cibber, son of Colley: 'Mark first the youth who takes the foremost place, / And thrusts his person full into your face. / With all thy Father's virtues blest, be born!' (131-33). 'Imitations' directs our attention to 'A manner of expression used by Virgil,' and quotes Eclogues 8.17: 'Nascere, praeque diem veniens age, Lucifer, almum.' But here 'nascere' means not 'be born' but 'arise,' and while for Virgil 'Lucifer' was simply the morning star, for Christian readers it suggests Satan, and indeed Pope lops off the last word of the line to emphasize 'Lucifer.' He continues on the theme of manner of expression: 'As also that of Patriis virtutibus. Ecl. 4.' Eclogue 4 is of course the prophetic eclogue hailing a renewal of the world under a child yet to be born, who will rule a world pacified by his father's virtues (17). Following in the medieval tradition that Virgil was prophesying the birth of Christ, Pope himself had drawn heavily on this Eclogue in composing his Messiah (1712). There is in fact nothing remarkable about either of these Latin expressions; they are invoked simply as a means of making the Cibbers, father and son, ridiculous by incongruity.

These examples show Pope steadily reminding his readers of the majestic figures of one of the monuments of classical culture, and thus pointing up the smallness and the ephemerality of the dominant strain in English culture of the 1720s. At the same time, by quoting so substantially from the best-known episodes in a poem familiar to the majority of the readers whose attention Pope hoped to engage, he encourages these readers to join with him against the stupidity and falsity of the contemporary cultural scene. By quoting what his readers are liable to recognize, Pope asserts community with them and so enlists them in 
his party; in the words of Bernard Darwin, both parties 'are thereupon seen to persons of taste and discrimination. ${ }^{21}$

In Brossette's edition, Boileau is represented as imitating modern authors only infrequently; Pope does so considerably more often. These 'Imitations,' frequently characterized as either 'allusions' or 'parodies' of particular passages (terms Pope never uses of his classical sources), function essentially in the same way as the imitations of the classics. The author most frequently cited is Milton (eight references to Paradise Lost); the others are writers Pope regarded as genuinely 'polite': Dryden, Denham, Garth, Waller, Cowley, Halifax, Roscommon, Addison, Young - with one exception. Sir Richard Blackmore, pilloried in the poem, contributes the phrase 'sea of heads' (2.380 [i.e., 378]) from his paraphrase of the book of Job. Pope thought the expression ridiculous, and had quoted it in Peri Bathous, as Sutherland explains in his note on the passage; ironically, by quoting it here he may have given it respectability, for it seems a perfectly natural and not uncommon expression in descriptions of crowds today.

Finally, it is important to recognize that Pope's use of 'Imitations' in The Dunciad is quite different from his handling of classical precedents in The Rape of the Lock. The point can be made by reference to Pope's longest single imitation of a classical passage in all his original poetry, Clarissa's speech at the opening of canto 5 of The Rape of the Lock. This passage was added to the poem as it appeared in the Works of 1717 , and it seems likely that the idea of adapting Sarpedon's speech to Glaucus from Iliad 12 occurred to Pope as he was preparing the third volume of his translation, which included book 12 , and was also published in 1717. Pope had translated the whole episode years before; it had appeared in Tonson's Poetical Miscellanies in 1709. I suppose that most of us, if challenged to produce an instance in which knowledge of the original adds substantially to the effect of the imitation, would name this passage. The brilliant transposition of the warrior's credo to the life of the coquette touches the speech with a special pathos, and Clarissa's final positive recommendation gains force from the contrast with Sarpedon's despairing conclusion. Yet Pope withheld the reference that would lead his mere English readers to Sarpedon's speech. There is no footnote to this passage in the 1717 edition, though there is one a few lines further on, relating the battle-scene that follows to Iliad 20. Not until the 1736 edition of his Works did Pope give this laconic

21 Introduction to The Oxford Dictionary of Quotations (2nd. ed, London: Oxford University Press, 1956), xiv. 
note: 'Parody of the speech of Sarpedon to Glaucus in Homer. ${ }^{22}$ And so it remained in the editions published in his lifetime.

Unlike The Rape of the Lock, The Dunciad could hardly be understood, let alone appreciated, by readers who did not possess special knowledge: a detailed acquaintance with the book trade, authorship, and publishing as well as familiarity with classical and modern poetry. By adopting Brossette's system of annotation, Pope provided his readers with a substantial body of reference material, while simultaneously mocking what he considered false scholarship. As J. Paul Hunter has argued, the result was a shift in the way readers engaged, or expected to engage, with literary texts: Pope 'shifted the burden of discovery from learning and previous reading to readerly work within the text. ${ }^{23}$ Pope himself felt the attraction of this new model of presentation with its increased control over readers' responses; seen in this light, William Warburton was chosen to play Claude Brossette to Pope's Boileau. ${ }^{24}$ As Pope's literary executor, Warburton extended Brossette's tripartite annotation to all of the poetry in his 1751 edition of Pope's works. In the case of Clarissa's speech, he retained Pope's brief indication of the parody of Homer. He added the incorrect statement that Clarissa was a 'New Character introduced in the subsequent Editions, to open more clearly the moral of the Poem.' He appended the entire speech of Sarpedon under the heading 'Imitations. ${ }^{25}$ In thus making the reader's experience of reading The Rape of the Lock similar to the experience of reading The Dunciad, Warburton may have been doing what Pope encouraged him to do, but one may yet question the wisdom of this course of action. The elaborate machinery that is appropriate to Pope's persuasive scheme in The Dunciad seems out of place in The Rape of the Lock. In the mock-heroic, imitation is invention in more ways than one.

\section{JOHN BAIRD}

University of Toronto

22 The Works of Alexander Pope, Esq. (London: Lintot, 1736), 1.168.

23 J. Paul Hunter, 'From Typology to Type,' in Margaret J. M. Ezell and Katherine O'Brien O'Keefe, eds., Cultural Artifacts and the Production of Meaning (Ann Arbor: University of Michigan Press, 1994), 65-66.

24 James McLaverty, Pope, Print, and Meaning (Oxford: Oxford University Press, 2001), 209-41, especially 211.

25 The Works of Alexander Pope Esq. in Nine Volumes Complete (London: Knapton, 1751), 1:255. 